\title{
Effects of Torrefaction Pretreatment and Mg-Al Modified HZSM-5 Catalysts on Components Distribution in Bio- Oils from Camphorwood Pyrolysis
}

\author{
Wei-Dong Liu, Shan-Jian Liu,* Yong-Jun Li, An Zhao, Dong-Mei Bi, and \\ Zhi-Dong Lin
}

\begin{abstract}
Torrefaction pretreatment conducted at a low temperature is an important technique for refining the bio-oil and improving the production of some chemicals in the bio-oil (e.g. aromatic hydrocarbons). In this work, the effects of torrefaction temperature and catalysts on the yields of pyrolysis products and components distribution in the bio-oils were analyzed. The weak acid sites shifted to higher temperature as the HZSM-5 was modified by $\mathrm{Mg}^{2+}$ or $\mathrm{Al}^{3+}$. The catalytic pyrolysis from camphorwood was done at pyrolysis of $450{ }^{\circ} \mathrm{C}$ and torrefaction temperature of $200{ }^{\circ} \mathrm{C}$. The catalysts remarkably influenced the yields of bio-oil and components distribution. The catalysts increased the production of phenols. The content of phenols in the resulting bio-oil exhibited the following trend: HZSM- $5<\mathrm{MgO}$ modified HZSM-5 < $\mathrm{Al}_{2} \mathrm{O}_{3}$-modified HZSM-5. In addition, the content of 2,6-dimethoxyphenol was the highest among all phenol components $(5.58 \%)$. The production of aldehydes was remarkably improved by the $\mathrm{Al}_{2} \mathrm{O}_{3}$-modified $\mathrm{HZSM}-5$, resulting in a maximum content of $8.21 \%$. Thus the torrefaction temperature and catalysts would refine the bio-oil (such as the acid value decreased) and significantly improve the contents of components (such as D-allose, 2,6-dimethoxy-4-(2-propeny)-phenol, 1,2,4-trimethoxybenzene, and 2,6-dimethoxyphenol). The results provide a theoretical basis for the resource recovery of biomass.
\end{abstract}

Keywords: Biomass; Torrefaction; Mg-Al modified; HZSM-5; Bio-oil

Contact information: School of Agricultural Engineering and Food Science, Shandong University of Technology, Zibo, Box 255000, China; *Corresponding author: liushanjian08@163.com

\section{INTRODUCTION}

Since the industrial revolution, the production of chemicals has relied on fossil feedstock. However, for environmental protection, increasing attention has been placed on utilizing sustainable and abundant biomass for fuels and high-value chemicals. Biomass can be converted into a variety of chemicals by thermochemical technologies, and less secondary pollutants will be produced during this process (Sheldon 2014; Sharma et al. 2015; Kabir and Hameed 2017). By utilizing thermochemical technologies for the production of chemicals in an ideal manner, zero emission standards and energy security could both be achieved. With the ongoing energy crisis and accompanying environmental issues plaguing countries around the world, there has been an interest in using biomass to develop clean fuels and chemicals, because it is the only sustainable source of carbon to meet the energy, chemical, and material needs of society (Cai et al. 2014; Sommerhuber et al. 2015).

Catalytic pyrolysis is a process that efficiently utilizes resources to convert biomass into high-quality bio-oil, bio-gas, and bio-char under anaerobic or hypoxic conditions at a high temperature (Bender et al. 2018; Bi et al. 2019). The incorporation of catalysts could 
decrease the pyrolysis temperature and increase the production of target chemicals (Hassan et al. 2016; Kan et al. 2016; Yildiz et al. 2016). Therefore, high-efficiency catalysts could enhance selectivity of pyrolysis products and reduce energy consumption (Zhang et al. 2015; Schultz et al. 2017).

However, biomass contains a relatively high content of oxygen compared with fossil fuels (Masnadi et al. 2014), which leads to poor bio-oil traits, including a high-water content and high acidity (Prabu et al. 2017). Torrefaction pretreatment of biomass at low temperatures is effective in reducing the acidity and oxygen content of bio-oil and increasing the calorific value of bio-oil. Medic et al. (2012) torrefied corn straw on a fixed bed at $200{ }^{\circ} \mathrm{C}, 250{ }^{\circ} \mathrm{C}$, and $300{ }^{\circ} \mathrm{C}$. The $\mathrm{O} / \mathrm{C}$ ratio decreased from 1.11 to 0.60 , and the energy density increased by $19 \%$ as corn straw was torrefied (Medic et al. 2012). Chen et al. (2018) pyrolyzed rubber chips at torrefaction temperatures of $200{ }^{\circ} \mathrm{C}, 250{ }^{\circ} \mathrm{C}$, and 300 ${ }^{\circ} \mathrm{C}$. The content of oxygenated acids and aldehydes in bio-oil decreased, and the bio-oil yield decreased when the torrefaction temperature increased (Chen et al. 2018). Chen et al. (2015) pyrolyzed cotton stalks on a fixed bed at torrefaction temperatures of $220{ }^{\circ} \mathrm{C}, 250$ ${ }^{\circ} \mathrm{C}$, and $280{ }^{\circ} \mathrm{C}$, respectively. The $\mathrm{H} / \mathrm{C}$ ratio of pyrolysis production increased after cotton stalks were torrefied. The content of $\mathrm{CH}_{4}$ and $\mathrm{H}_{2}$ in the bio-gas noticeably increased (Chen et al. 2015). Above all, the yield of bio-oil decreased, the content of acid in the bio-oil decreased, and the content of phenols increased as the torrefaction temperature increased. Therefore, torrefaction affected the cracking process of the three biomass components (cellulose, hemicelluloses, and lignin) and the distribution of components in the bio-oil.

HZSM-5 zeolite has been incorporated in previous studies due to its numerous advantages, including its ability to decrease the oxygen and acidity of bio-oil, its ability to improve the stability and quality of bio-oil, and its selectivity towards cracking, isomerization, and aromatization reactions. HZSM-5 zeolite was used to pyrolyze Pinus taeda at $500{ }^{\circ} \mathrm{C}$ (Hilten et al. 2013). The content of organic acids and aldehydes in bio-oil noticeably decreased, while the content of L-glucose increased. Beech was pyrolyzed in a tandem microreactor at $400{ }^{\circ} \mathrm{C}, 500{ }^{\circ} \mathrm{C}$, and $600{ }^{\circ} \mathrm{C}$. The content of L-glucose, acetic acid, aldehydes, ketones, and phenols in bio-oil was higher than that in non-catalytic bio-oil. The content of oxygenated hydrocarbons and aromatic compounds increased with increasing addition of HZSM-5. Moreover, the aromatic compounds increased with the increase of HZSM-5 zeolite loading (Karagöz et al. 2016). HZSM-5 catalyzed the pyrolysis of pine, cellulose, and lignin. The formation of aromatic compounds was promoted, and the formation of coke was inhibited (Mullen and Boateng 2015; Xue et al. 2018).

Using $\mathrm{MgO}$ as the catalyst to pyrolyze cotton stalks on a fixed bed at $550{ }^{\circ} \mathrm{C}$ and the mass ratio of $\mathrm{MgO}$ to cotton stalks of 2:1, Zeng et al. (2018) showed that the yield of bio-char decreased from $48.21 \%$ to $22.05 \%$ when the torrefaction temperature was raised from $200{ }^{\circ} \mathrm{C}$ to $350{ }^{\circ} \mathrm{C}$. Therefore, $\mathrm{MgO}$ could greatly reduce the yield of bio-char. The addition of $\mathrm{Al}^{3+}$ during the pyrolysis of wheat straw could promote the decarboxylation reaction of macromolecular organics, causing a reduction of oxygen content in the pyrolysis products (Pütün 2010; Navarro et al. 2018).

At present, research on the effects of torrefaction or catalysts have only analyzed impacts associated with the bio-oil yield and distribution of components in bio-oil (Zhang et al. 2013; Chagas et al. 2016; Du et al. 2016). In this paper, the effects of torrefaction and catalysts on biomass pyrolysis were investigated. $\mathrm{MgO}$ and $\mathrm{Al}_{2} \mathrm{O}_{3}$-modified HZSM-5 zeolites were introduced in the pyrolysis of torrefaction camphorwood. Subsequently, the yield of bio-oil, bio-gas, and bio-char along with the distribution of components in the biooil were all investigated. The results of this paper could provide basic data for the bio-oil upgrading, and the production of high-value chemicals using biomass. 


\section{EXPERIMENTAL}

\section{Materials}

Camphorwood is an abundant resource harvested in the southern part of the world and China. Camphorwood is used as an urban street tree because its ability to absorb smoke, dust, and noxious gas. It is a commonly employed wood in the construction and furniture industry because of its hard texture and ability to repel insects. There is a lot of waste generated, including leaves, branches, roots, and sawdust, during the utilization of camphorwood. Therefore, camphorwood was employed as the pyrolysis material in this study. The diameter of particles was 40 to 60 mesh. The camphorwood was dried in a thermostatic air bio-power driven drying oven for $12 \mathrm{~h}$ at $105^{\circ} \mathrm{C}$.

\section{Torrefaction of Camphorwood}

Torrefaction removes free water and bound water from the biomass. This could lead to a reduction of moisture and oxygen content. After torrefaction, the content of water and volatiles in biomass decreases, and the content of fixed carbon increases (Wang et al. 2017). The content of $\mathrm{H}$ and $\mathrm{O}$ in camphorwood decreases, while the content of $\mathrm{C}$ increases with increased torrefaction temperature (Zheng et al. 2018). Torrefaction promotes the depolymerization of cellulose, hemicellulose, and lignin in biomass, which causes an increase of bio-oil yield and subsequent refinement of bio-oil (Zhang et al. 2018).

Torrefaction of camphorwood is conducted in a torrefaction box (Kejing, GSL1700X-VT; Hefei Ke Jing Materials Technology Co., Ltd, Hefei, China). The heating rate was $10^{\circ} \mathrm{C} / \mathrm{min}$, and the holding time was $30 \mathrm{~min}$. The torrefaction temperature of camphorwood was $200{ }^{\circ} \mathrm{C}, 250{ }^{\circ} \mathrm{C}$, or $300{ }^{\circ} \mathrm{C}$. To avoid the burning of camphorwood, nitrogen was passed through the torrefaction box with a flow rate of $100 \mathrm{~mL} / \mathrm{min}$.

The industrial and elemental analyses of camphorwood are shown in Table 1. Volatile matter exhibited the highest content within camphorwood, followed by fixed carbon and moisture content. Almost no ash was detected. Therefore, most of the pyrolysis of camphorwood was gas, including condensable gas and non-condensable gas. The condensable gas was condensed into the bio-oil. The contents of $\mathrm{C}$ and $\mathrm{O}$ were high, but the contents of $\mathrm{N}$ and $\mathrm{S}$ were low. The main components of bio-oil obtained by pyrolysis of camphorwood were $\mathrm{C}, \mathrm{H}$, and $\mathrm{O}$ compounds. Moreover, the hydrogen content was low, the oxygen content was high, and the calorific value of bio-oil was low. Therefore, decreasing the oxygen content and increasing the hydrogen content were the key factors for improving the quality of bio-oil. The three biomass components were detected by twostep acid hydrolysis. The monosaccharides obtained from biomass hydrolysis were detected by high performance liquid chromatography (HPLC) with a refractive index detector (Waters 2698, New York, USA). The three biomass components of camphorwood are shown in Table 1. The elemental analysis results demonstrated that the content of $\mathrm{C}$, $\mathrm{H}$, and $\mathrm{O}$ were the main elements in camphorwood, with values amounting to $46.58 \mathrm{wt} \%$, $5.07 \mathrm{wt} \%$, and $46.93 \mathrm{wt} \%$, respectively. The content of $\mathrm{C}$ increased with the increase of torrefaction temperature. The content of $\mathrm{H}$ peaked when the torrefaction temperature was $200{ }^{\circ} \mathrm{C}$. The content of $\mathrm{O}$ decreased with the increase of torrefaction temperature. The volatiles content was the highest in camphorwood at torrefaction temperature of $200{ }^{\circ} \mathrm{C}$. The camphorwood was enriched with fixed carbon as the torrefaction temperature increased. The content of cellulose decreased with the increase of torrefaction temperature. The content of hemicelluloses was the highest at a torrefaction temperature of $200{ }^{\circ} \mathrm{C}$, and the lowest content was observed at a torrefaction temperature of $300{ }^{\circ} \mathrm{C}$. The content of lignin increased with the increase of torrefaction temperature. 
Table 1. Proximate and Elemental Analysis of Camphorwood

\begin{tabular}{|c|c|c|c|c|}
\hline & \multirow{2}{*}{$\begin{array}{c}\text { Original } \\
\text { Camphorwood }\end{array}$} & \multicolumn{3}{|c|}{ Torrefaction Temperature $\left({ }^{\circ} \mathrm{C}\right)$} \\
\hline & & 200 & 250 & 300 \\
\hline \multicolumn{5}{|l|}{ Element (wt\%) } \\
\hline $\mathrm{C}_{a d}$ & 46.58 & 51.24 & 55.41 & 60.67 \\
\hline $\mathrm{H}_{a d}$ & 6.07 & 6.44 & 6.36 & 4.25 \\
\hline $\mathrm{N}_{a d}$ & 0.36 & 0.65 & 0.65 & 0.73 \\
\hline $\mathrm{O}_{a d}$ & 46.99 & 41.67 & 37.58 & 34.35 \\
\hline \multicolumn{5}{|c|}{ Composition (wt\%) } \\
\hline$M_{\mathrm{ad}}$ & 5.60 & 0.00 & 0.00 & 0.00 \\
\hline$A_{\text {ad }}$ & 1.00 & 4.06 & 4.66 & 3.02 \\
\hline$V_{\mathrm{ad}}$ & 78.97 & 80.67 & 77.60 & 68.16 \\
\hline$F C_{\text {ad }}$ & 14.43 & 15.27 & 17.74 & 28.82 \\
\hline \multicolumn{5}{|c|}{ Three biomass components (wt $\%$ ) } \\
\hline Cellulose & 49.11 & 47.01 & 45.62 & 24.04 \\
\hline Hemicellulose & 12.16 & 14.90 & 12.41 & 0.40 \\
\hline Lignin & 23.28 & 27.05 & 33.91 & 75.63 \\
\hline
\end{tabular}

Note: $M_{a d}, A_{a d}, V_{a d}$, and $F C_{a d}$ represented moisture, ash, volatiles, and fixed carbon on an air-dried basis, respectively. $\mathrm{C}_{a d}, \mathrm{H}_{a d}, \mathrm{~N}_{a d}, \mathrm{~S}_{a d}$, and $\mathrm{O}_{a d}$ represented carbon, hydrogen, nitrogen, sulfur, and oxygen in the air drying base, respectively.

\section{Catalysts}

HZSM-5 zeolite was used as the catalyst, which had a ratio of silicon to aluminum of 38 and a specific surface area of $320 \mathrm{~m}^{2} / \mathrm{g}$. The catalyst was calcined in a tube furnace at $600{ }^{\circ} \mathrm{C}$ for $1 \mathrm{~h}$ before pyrolysis. The mass ratio of $\mathrm{HZSM}-5$ to $\mathrm{MgO}$ (or $\mathrm{Al}_{2} \mathrm{O}_{3}$ ) was 1:1, and the concentration of impregnated solution was $0.5 \mathrm{~mol} / \mathrm{L}$.

The metal oxide was loaded on the HZSM-5 zeolite. Subsequently, the surface acid site activity was reduced, and the microporous structure of molecular sieve was adjusted, thereby improving the catalytic shape-selective performance of HZSM-5 zeolite (Trubetskaya et al. 2018). The common method for loading metal oxides on HZSM-5 zeolite is through ion exchange or an impregnation method (Chen et al. 2017). An impregnation method was employed in this paper.

The preparation steps of metal oxide-modified HZSM-5 were as follows: the mixture of $\mathrm{HZSM}-5$ and $\mathrm{MgCl}_{2}$ (or $\mathrm{AlCl}_{3}$ ) solution was stirred in a $\mathrm{WH} 240$-plus constant temperature magnetic heating stirrer (Efson Biotechnology Co., Ltd., China) at $25{ }^{\circ} \mathrm{C}$ for $6 \mathrm{~h}$. Then, the mixture was filtered with a water recirculation vacuum pump. The filtered HZSM-5 was dried at $110{ }^{\circ} \mathrm{C}$ for $4 \mathrm{~h}$. Finally, the metal oxide-modified HZSM-5 was calcined at $500{ }^{\circ} \mathrm{C}$ for $3 \mathrm{~h}$, and the heating rate was $50{ }^{\circ} \mathrm{C} / \mathrm{h}$. In addition, the chemical reaction of $\mathrm{MgCl}_{2}$ (or $\mathrm{AlCl}_{3}$ ) during the calcination was $\mathrm{MgCl}_{2} \rightarrow \mathrm{MgO}+\mathrm{Cl}_{2}\left(2 \mathrm{AlCl}_{3}\right.$ $\rightarrow \mathrm{Al}_{2} \mathrm{O}_{3}+3 \mathrm{Cl}_{2}$ ).

\section{Pyrolysis of Camphorwood}

The pyrolysis of camphorwood was carried out in a horizontal tube furnace in a nitrogen atmosphere with a $\mathrm{N}_{2}$ flow rate of $40 \mathrm{~mL} / \mathrm{min}$. The heating rate of horizontal tube furnace was 15 to $20^{\circ} \mathrm{C} / \mathrm{min}$, and the pyrolysis residence time was $2 \mathrm{~min}$. The experiment consisted of three parts: the direct pyrolysis of camphorwood, pyrolysis using the torrefaction camphorwood, and in situ pyrolysis of camphorwood and catalyst. The pyrolysis temperature was $400{ }^{\circ} \mathrm{C}, 450{ }^{\circ} \mathrm{C}, 500^{\circ} \mathrm{C}, 550{ }^{\circ} \mathrm{C}$, or $600{ }^{\circ} \mathrm{C}$. The mass ratio of 
camphorwood to catalyst was $1: 1$.

The quartz reaction tube was placed in a horizontal tube furnace and heated. To avoid the production of ash from the camphorwood, a flow of nitrogen was introduced to create a hypoxic environment. To enhance the condensation effect of pyrolysis gas, twostage condensation was adopted, as shown in Fig. 3. The bio-oil was extracted with absolute ethanol (analytical grade). The yields of bio-oil ( $\left.Y_{\text {bio-oil }}\right)$, bio-gas $\left(Y_{\text {bio-gas }}\right)$, and biochar (Ybio-char $)$ were analyzed as shown in Eqs. 1, 2, and 3, respectively,

$$
\begin{aligned}
& Y_{\text {bio-oil }}=\frac{m_{\text {bio-oil }}}{m_{\text {biomass }}} \\
& Y_{\text {bio-gas }}=\frac{m_{\text {biomass }}-m_{\text {bio-oil }}-m_{\text {bio-char }}}{m_{\text {biomass }}} \\
& Y_{\text {bio-char }}=1-Y_{\text {bio-oil }}-Y_{\text {bio-gas }}
\end{aligned}
$$

where mbio-oil, mbiomass, and mbio-char were the mass of bio-oil, g, the mass of camphorwood, $\mathrm{g}$, and the mass of bio-char, $\mathrm{g}$, respectively.

The bio-oil components were analyzed by gas chromatography-mass spectrometry (GC-MS; Model 5972N, Agilent, Santa Clara, USA). The pyrolysis components with a relative content greater than $1 \%$ were selected for analysis. The heating rate was $5{ }^{\circ} \mathrm{C} / \mathrm{min}$. The carrier gas was $\mathrm{He}(>99.99 \%)$. The flow rate was $5 \mathrm{~mL} / \mathrm{min}$. The split ratio was 30:1. The ion source temperature was $240{ }^{\circ} \mathrm{C}$. The interface temperature was $250{ }^{\circ} \mathrm{C}$.

\section{RESULTS AND DISCUSSION}

\section{Characterization of Catalysts}

The SEM images presents the catalysts of MgO-modified HZSM-5 (Fig.1a) and $\mathrm{Al}_{2} \mathrm{O}_{3}$-modified HZSM-5 (Fig.1b). The loading quantities of $\mathrm{Mg}$ and $\mathrm{Al}$ are listed in Table 2, and they were detected by ICP-MS (Inductively Coupled Plasma Mass Spectrometry, USA, 7500ce). The contents of $\mathrm{Mg}$ and $\mathrm{Al}$ in HZSM-5 were 13.1 and $51.8 \mathrm{mg} / \mathrm{kg}$. The content of $\mathrm{Mg}$ increased up to $3200 \mathrm{mg} / \mathrm{kg}$ as the HZSM-5 was modified by the MgO. Meanwhile, the content of Al increased up to $13580 \mathrm{mg} / \mathrm{kg}$ as the HZSM-5 was modified by the $\mathrm{Al}_{2} \mathrm{O}_{3}$. So, the $\mathrm{Mg}$ and $\mathrm{Al}$ were successfully loaded on the surface of HZSM-5. The acidic properties of HZSM-5, MgO-modified HZSM-5, and $\mathrm{Al}_{2} \mathrm{O}_{3}$-modified HZSM-5 were studied by the TPD (Temperature Programmed Desorption, USA, AutochemII 2920), as shown in Fig. 1c. Experimental conditions: The mass of sample was $50 \mathrm{mg}$ (20-30 mesh). The carrier gas was He and the purge time of $\mathrm{He}$ was $40 \mathrm{~min}$ at $400{ }^{\circ} \mathrm{C}$. The $\mathrm{NH}_{3}$ would be absorbed with a flow rate of $50 \mathrm{~cm}^{3} / \mathrm{min}$ of a mixed gas $\left(\mathrm{NH}_{3}-\mathrm{He}\right)$ as the temperature decreased to $110{ }^{\circ} \mathrm{C}$. The temperature increased up to $150{ }^{\circ} \mathrm{C}$ when the $\mathrm{NH}_{3}$ reached the saturation state. He was used as a purge for $30 \mathrm{~min}$ in order to remove the physically adsorbed $\mathrm{NH}_{3}$. Then the temperature increased up to $600{ }^{\circ} \mathrm{C}$ with a heating rate of $10{ }^{\circ} \mathrm{C} / \mathrm{min}$. Two peaks were detected in the TPD spectrum of HZSM-5. The desorption peak at $233{ }^{\circ} \mathrm{C}$ was attributed to the weak acid sites and the desorption peak at $362.5{ }^{\circ} \mathrm{C}$ was attributed to the strong acid sites. In addition, the weak acid sites shifted to the higher temperature as HZSM-5 was modified with $\mathrm{Mg}^{2+}$ or $\mathrm{Al}^{3+}$. The strong acid sites shifted to higher temperature as HZSM-5 was modified by $\mathrm{Mg}^{2+}$. Meanwhile, the strong acid sites shifted to lower temperature as HZSM-5 was modified with $\mathrm{Al}^{3+}$. 

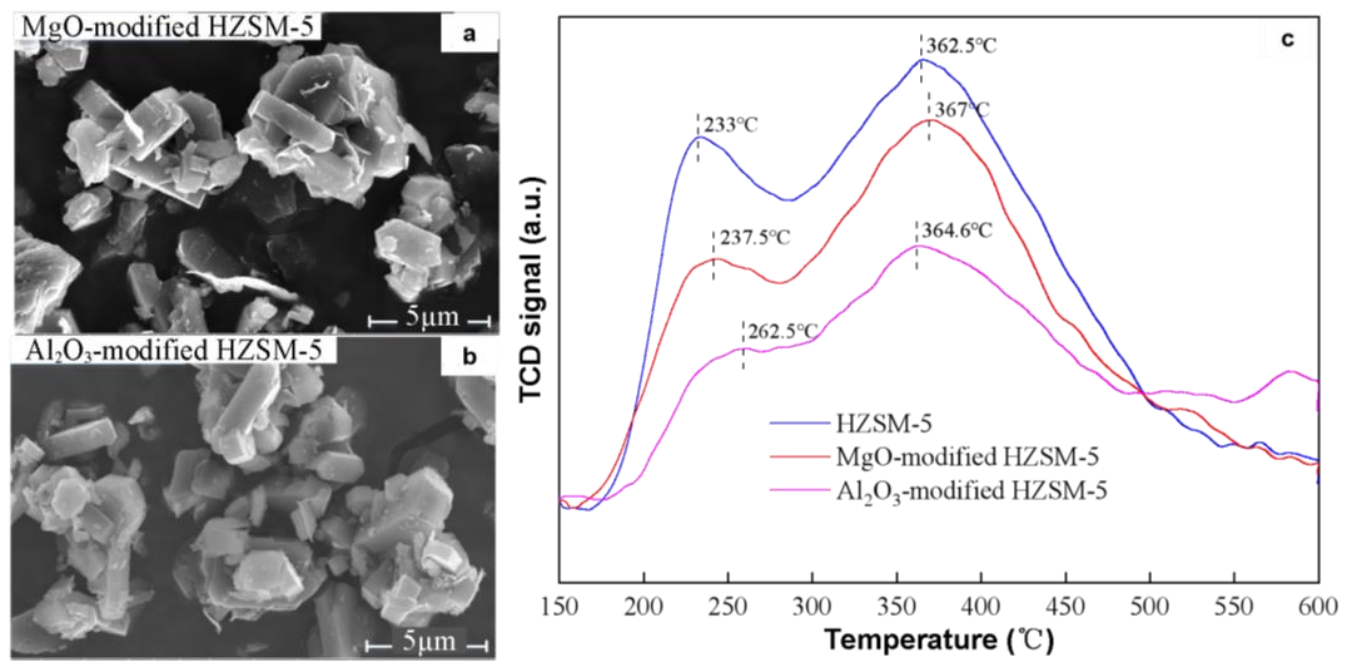

Fig. 1. SEM of MgO-modified HZSM-5 (a) and $\mathrm{Al}_{2} \mathrm{O}_{3}$-modified $\mathrm{HZSM}-5$ (b); $\mathrm{NH}_{3}-\mathrm{TPD}$ curve (C)

Table 2. Catalyst Content of $\mathrm{Mg}$ and $\mathrm{Al}$

\begin{tabular}{|c|c|c|c|}
\hline & HZSM-5 & MgO-modified HZSM-5 & $\mathrm{Al}_{2} \mathrm{O}_{3}$-modified HZSM-5 \\
\hline $\mathrm{Mg}(\mathrm{mg} / \mathrm{kg})$ & $13.07 \pm 0.47$ & $3204.22 \pm 67$ & $6.94 \pm 0.04$ \\
\hline $\mathrm{Al}(\mathrm{mg} / \mathrm{kg})$ & $51.79 \pm 5$ & $15.48 \pm 1.42$ & $13578.6 \pm 58$ \\
\hline
\end{tabular}

\section{Products of Pyrolysis from Camphorwood}

The yields of bio-oil, bio-gas, and bio-char from camphorwood are shown in Fig. 2a. The yield of bio-oil first increased then decreased with the increase of pyrolysis temperature. The yields of bio-oil were $45.3 \%$ and $45.4 \%$ at 450 and $500{ }^{\circ} \mathrm{C}$, respectively. Therefore, the biomass was more completely degraded at 450 and $500{ }^{\circ} \mathrm{C}$ than other pyrolysis temperatures. When the pyrolysis temperature was lower than $450{ }^{\circ} \mathrm{C}$, the pyrolysis of camphorwood was incomplete, resulting in the production of tar and bio-char. The yield of bio-char was the highest at $400{ }^{\circ} \mathrm{C}$. When the camphorwood was directly pyrolyzed, the difference between bio-oil yields was not significant at 450 and $500{ }^{\circ} \mathrm{C}$. In order to obtain a greater content of high-value chemicals, a higher yield of bio-oil is desired. However, a high pyrolysis temperature also leads to an increase in the energy consumption and incurs a greater economic cost. Thus, the optimal pyrolysis temperature was judged to be $450{ }^{\circ} \mathrm{C}$ for camphorwood.

Figure $2 \mathrm{~b}$ shows the yield of bio-oil, bio-gas, and bio-char from camphorwood at torrefaction temperatures of $200{ }^{\circ} \mathrm{C}, 250^{\circ} \mathrm{C}$, and $300^{\circ} \mathrm{C}$. The pyrolysis temperature for this condition was $450{ }^{\circ} \mathrm{C}$. The yield of bio-oil deceased with increasing torrefaction temperature because the mass of camphorwood decreased and the bio-char yield increased after torrefaction pretreatment. The content of ash decreased after torrefaction, as demonstrated in Table 1. When the torrefaction temperature was increased from $250{ }^{\circ} \mathrm{C}$ to $300{ }^{\circ} \mathrm{C}$, the yield of bio-oil markedly decreased from $44.4 \%$ to $27.4 \%$ (decreased by 38.3\%). The waste sawdust was pyrolyzed after it was torrefied (Yoo and Choi 2016). When the torrefaction temperature was higher than $280{ }^{\circ} \mathrm{C}$, the yield of bio-oil markedly deceased. The reason for this phenomenon was that most of cellulose and hemicellulose in the biomass were decomposed when the torrefaction temperature was higher than $280^{\circ} \mathrm{C}$. Compared with direct pyrolysis, the bio-oil yield at a torrefaction temperature of $200{ }^{\circ} \mathrm{C}$ 
was higher. But at torrefaction temperatures of $250{ }^{\circ} \mathrm{C}$ and $300{ }^{\circ} \mathrm{C}$, the bio-oil yields were lower than that of direct pyrolysis. This could be attributed to the fact that the cellulose and hemicellulose in the biomass were decomposed when the torrefaction temperature was higher than $250{ }^{\circ} \mathrm{C}$. In order to obtain a high bio-oil yield and high-quality bio-oil, the optimal torrefaction temperature of camphorwood pyrolysis was $200{ }^{\circ} \mathrm{C}$.

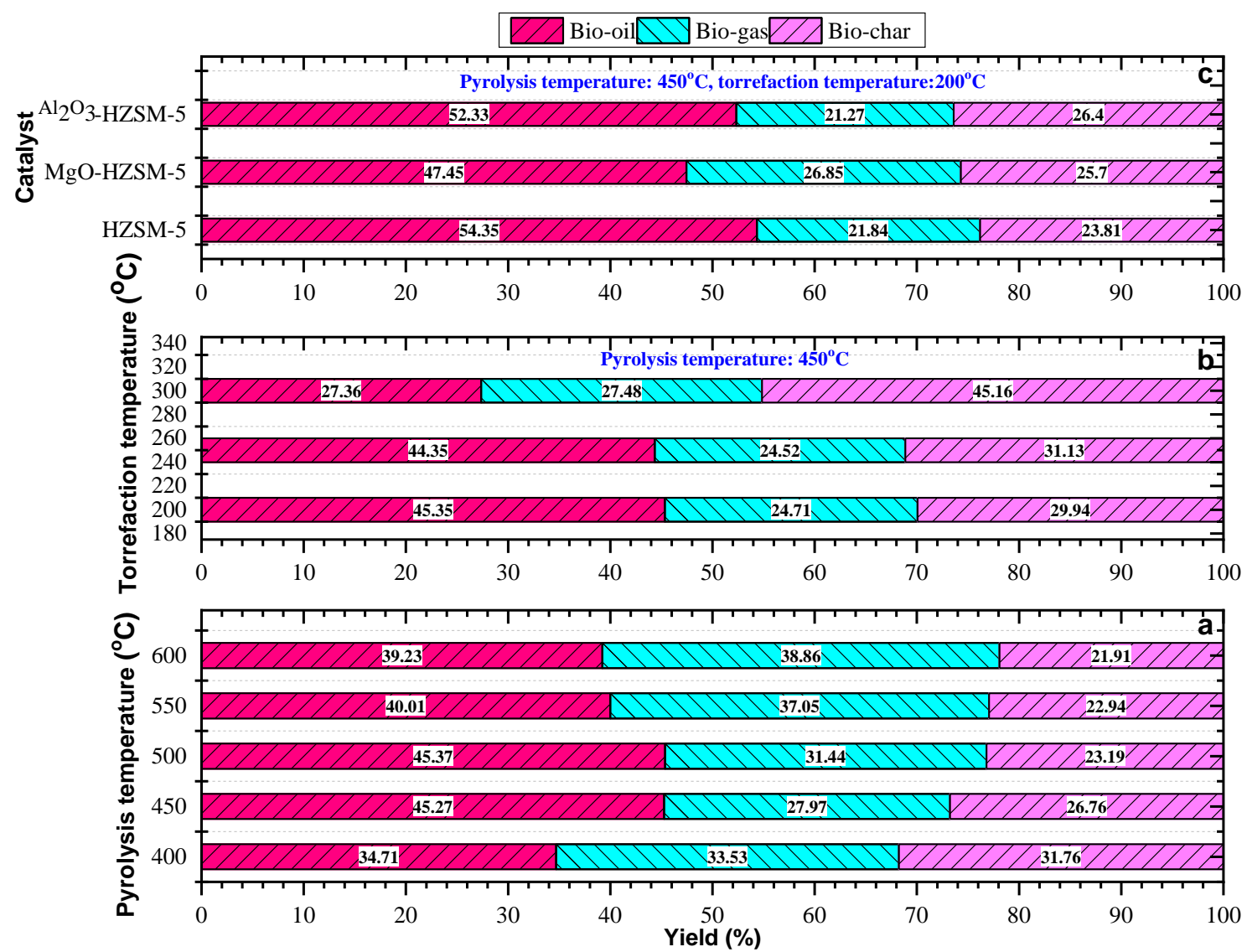

Fig. 2. Yields of bio-oil, bio-gas and bio-char at different pyrolysis temperatures (a), at different torrefaction temperatures (b), using different catalysts (c)

Figure 2c represents the yields of bio-oil, bio-gas, and bio-char resulting from catalytic pyrolysis. The pyrolysis temperature and torrefaction temperature were $450{ }^{\circ} \mathrm{C}$ and $200{ }^{\circ} \mathrm{C}$, respectively. The catalysts were HZSM-5, MgO-modified HZSM-5, and $\mathrm{Al}_{2} \mathrm{O}_{3}$-modified HZSM-5. The yields of catalytic bio-oil were higher than the yields resulting from bio-oil derived from direct pyrolysis and torrefaction pyrolysis. HZSM-5 could improve the yields of bio-oil in comparison to bio-oil derived from $\mathrm{MgO}$-modified HZSM-5 and $\mathrm{Al}_{2} \mathrm{O}_{3}$-modified HZSM-5. The rate of increase of bio-oil yield was more prominent than these of bio-gas and bio-char when the catalysts were used. The reason for this phenomenon was that the incorporation of catalysts could significantly inhibit the secondary decomposition of bio-oil. The bio-gas yield achieved the highest value for direct pyrolysis (28.0\%), and the bio-gas yield achieved the lowest value for $\mathrm{Al}_{2} \mathrm{O}_{3}$-modified HZSM-5 catalytic pyrolysis $(21.3 \%)$. The yields of bio-char decreased during catalytic pyrolysis. The bio-char yield followed the trend: HZSM-5 < MgO-modified HZSM-5 < $\mathrm{Al}_{2} \mathrm{O}_{3}$-modified HZSM-5. 


\section{Distribution in Bio-oil from Camphorwood}

Figure 3 shows components in the bio-oil derived from camphorwood. The pyrolysis temperature was $450{ }^{\circ} \mathrm{C}$. The torrefaction temperature was $200{ }^{\circ} \mathrm{C}$. The catalysts were HZSM-5, MgO-modified HZSM-5, and $\mathrm{Al}_{2} \mathrm{O}_{3}$-modified HZSM-5, respectively. The bio-oil contained various high-value chemicals, such as phenols, aldehydes, sugars, ketones, hydrocarbons, alcohols, and lipids. The content of phenols in bio-oil was the highest among all the chemical components. The content of phenols was the highest at pyrolysis temperature of $450{ }^{\circ} \mathrm{C}$ and torrefaction temperature of $200{ }^{\circ} \mathrm{C}$, leading to a content of $31.5 \%$. The torrefaction pretreatment and catalysts could all increase the production of aldehydes. The content of sugars reached the highest using HZSM-5 as the catalyst, $10.4 \%$. The $\mathrm{Al}_{2} \mathrm{O}_{3}$-modified HZSM improved the content of ketones. The content of lipids was lower than the other six compounds, and the content of lipids was highest at high temperatures $(4.27 \%)$.

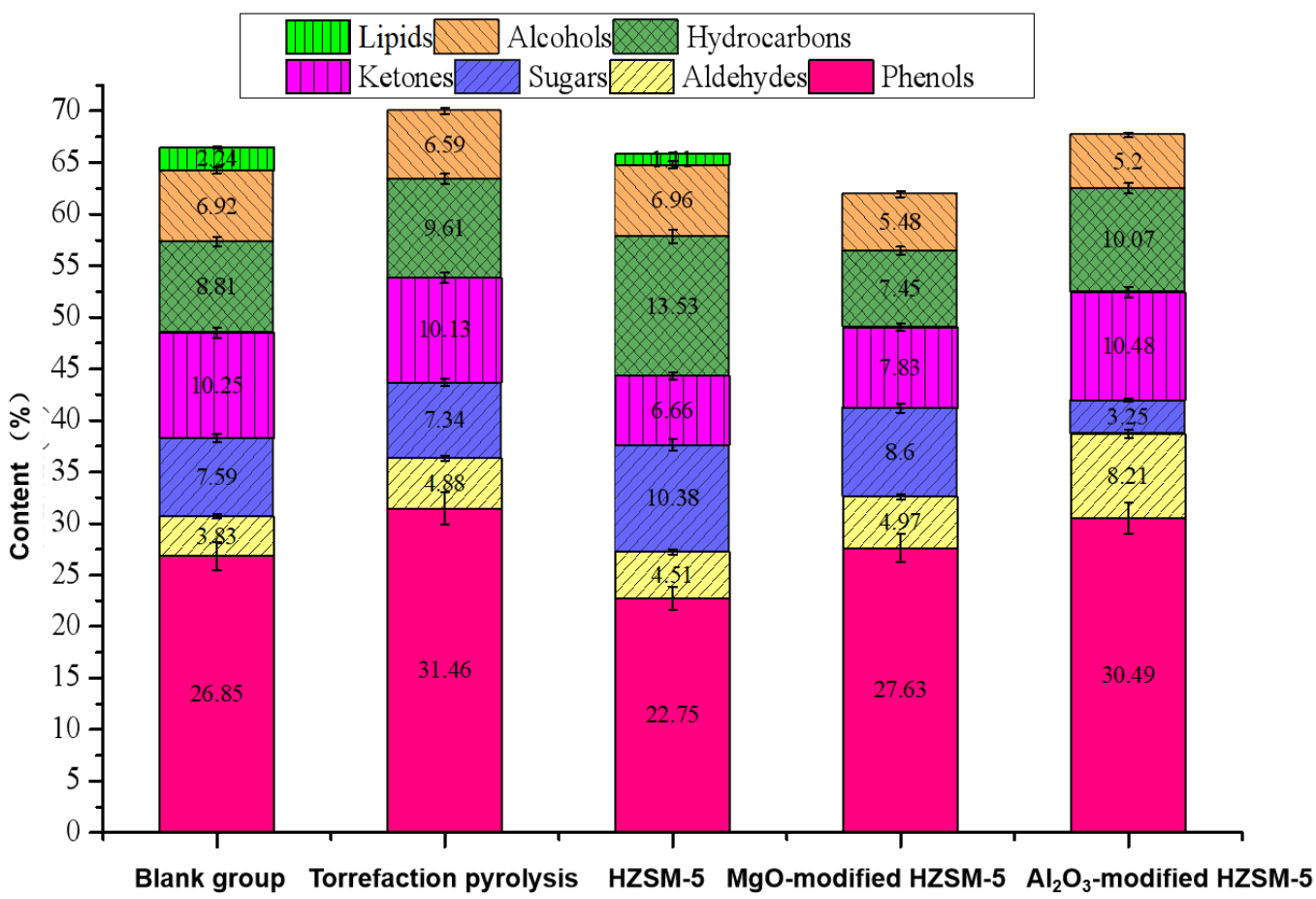

Fig. 3. Distribution of bio-oil using different catalysts

The phenols content followed the trend: HZSM-5 < MgO-modified HZSM-5 < $\mathrm{Al}_{2} \mathrm{O}_{3}$-modified HZSM-5. However, the content of phenols was lower than that resulting from torrefaction pyrolysis. The production of phenols was remarkably improved because of torrefaction pretreatment. The phenols were produced by the deoxygenation of lignin derivatives. When camphorwood was torrefied, the content of lignin increased, resulting in an increase in the content of phenols. The production of aldehydes was markedly increased by the incorporation of $\mathrm{Al}_{2} \mathrm{O}_{3}$-modified HZSM-5 catalyst. The phenol content in this trial was $8.21 \%$. The sugar content achieved the highest value when HZSM-5 was employed as the catalyst. The content of ketones was the highest when $\mathrm{Al}_{2} \mathrm{O}_{3}$-modified HZSM-5 was utilized as the catalyst. HZSM-5 could degrade lignin-derived oxygenates which improved the production of hydrocarbons. Therefore, the content of hydrocarbons was the highest when HZSM-5 was the catalyst. The content of alcohols was the highest when HZSM-5 was the catalyst, and it was the lowest when $\mathrm{Al}_{2} \mathrm{O}_{3}$-modified HZSM-5 was the catalyst. The content of lipids was $2.24 \%$ and $1.11 \%$ for direct pyrolysis and catalytic 
pyrolysis with HZSM-5 utilized as the catalyst, respectively. In addition, the torrefaction temperature was $200{ }^{\circ} \mathrm{C}$ and the catalysts were HZSM-5, MgO-modified HZSM-5, and $\mathrm{Al}_{2} \mathrm{O}_{3}$-modified HZSM-5. The results show that the categories of phenol, aldehyde, sugar, ketone and alcohol increased because of torrefaction pretreatment or use of catalyst. In addition, the contents of phenols (e. g. 2-methoxy- phenol, 2-methoxy-4-(1-propenyl)phenol, and 2,6-dimethoxy-4-(2-propenyl)-phenol) increased. The production of 1,2,4trimethoxybenzene and 1,2,3-trimethoxybenzene were increased after camphorwood was torrefied. The reason for this phenomenon was that the content of lignin increased because of torrefaction pretreatment. The cracking of lignin derivatives could result in the formation of polycyclic aromatic hydrocarbons, e. g., 1,2,4-trimethoxybenzene and 1,2,3trimethoxybenzene. The contents of desaspidinol and (2',3',4')-4-dihydro-6-methyl-2(3,4-dimethoxyphenyl)-3-2H-1-benzopyran-3,4-diol were $1.53 \%$ and 3.73\%, respectively. These compounds were classified as diols. Lignin could improve the formation of diols, as demonstrated in a previous study (Wang et al. 2018).

The content of D-allose was the highest in bio-oil when HZSM-5 was the catalyst (10.38\%). However, D-allose decreased to trace in bio-oil when MgO-modified HZSM-5 and $\mathrm{Al}_{2} \mathrm{O}_{3}$-modified HZSM-5 were the catalysts. The production of 3-furaldehyde was significantly improved by MgO-modified HZSM-5 and $\mathrm{Al}_{2} \mathrm{O}_{3}$-modified HZSM-5, and their contents were $2.45 \%$ and $4.19 \%$, respectively. The order of selectivity of aliphatic ketones, including 1,2-cyclopentanedione and 2-hydroxy-3-methyl-2-cyclopenten-1-one, was HZSM-5 < MgO-modified HZSM-5 < $\mathrm{Al}_{2} \mathrm{O}_{3}$-modified HZSM-5. The order of selectivity of aromatic ketones, such as (1S)- 7,7-trimethyl-bicyclo[2.2.1]heptan-2-one, was HZSM-5 < MgO-modified HZSM-5 < $\mathrm{Al}_{2} \mathrm{O}_{3}$-modified HZSM-5. Categories of phenols in catalytic bio-oil increased compared with the type of phenols derived from direct pyrolysis and torrefaction pyrolysis. However, the content of phenols did not markedly change. The selectivity of MgO-modified HZSM-5 for phenols was higher than HZSM-5 and $\mathrm{Al}_{2} \mathrm{O}_{3}$-modified HZSM-5. The selectivity of MgO-modified HZSM-5 for 1,6-anhydroá-D-glucopyranose (levoglucosan) was higher than $\mathrm{Al}_{2} \mathrm{O}_{3}$-modified HZSM-5. The content of acids was lower when HZSM-5 was the catalyst.

In summary, the order impact of different parameters on the bio-oil yield followed the trend: $\mathrm{HZSM}-5>\mathrm{Al}_{2} \mathrm{O}_{3}$-modified HZSM-5 > MgO-modified HZSM-5 > torrefaction pyrolysis $>$ direct pyrolysis. The content of phenols was the highest when camphorwood was torrefied at $200{ }^{\circ} \mathrm{C}$. The types of phenols increased markedly in catalytic bio-oil. In addition, the content of phenols was higher when $\mathrm{Al}_{2} \mathrm{O}_{3}$-modified HZSM-5 was the catalyst. The productions of aldehydes, sugars, hydrocarbons and alcohols were enhanced for catalytic pyrolysis. The contents of ketones decreased when $\mathrm{HZSM}-5$ and $\mathrm{MgO}-$ modified HZSM-5 were the catalysts.

\section{CONCLUSIONS}

1. When the pyrolysis temperature was $450^{\circ} \mathrm{C}$, the yield of bio-oil was the highest. The contents of phenols and ketones in bio-oil were highest at $450{ }^{\circ} \mathrm{C}$, amounting to values of $26.8 \%$ and $10.2 \%$, respectively. The highest content of hydrocarbons was $8.81 \%$ at $450{ }^{\circ} \mathrm{C}$. The main components of aldehydes included 3-furaldehyde and syringaldehyde, $2.81 \%$ and $1.02 \%$, respectively.

2. When the torrefaction temperature was $200{ }^{\circ} \mathrm{C}$, the yield of bio-oil from camphorwood was highest and it was $45.4 \%$. The types of phenols increased, and the phenols content 
increased up to $4.6 \%$. The sugars content at a torrefaction temperature of $200{ }^{\circ} \mathrm{C}$ increased two-fold compared with that at a torrefaction temperature of $300{ }^{\circ} \mathrm{C}$. The production of hydrocarbons was improved, and its content increased from $8.8 \%$ to $9.6 \%$.

3. The type of phenols in catalytic bio-oil increased compared with that in direct pyrolysis bio-oil and the torrefaction pyrolysis bio-oil. The production of aldehydes was markedly improved by the $\mathrm{Al}_{2} \mathrm{O}_{3}$-modified HZSM-5, and its content was $8.2 \%$. The content of sugars achieved the highest value when the HZSM-5 was the catalyst. The content of ketones was the highest when $\mathrm{Al}_{2} \mathrm{O}_{3}$-modified HZSM-5 was the catalyst. The order of selectivity of aliphatic ketones, including 1,2-Cyclopentanedione and 2hydroxy-3-methyl-2- cyclopenten-1-one, was HZSM-5 < MgO-modified HZSM-5 < $\mathrm{Al}_{2} \mathrm{O}_{3}$-modified HZSM-5.

\section{ACKNOWLEDGEMENTS}

This work was sponsored by the Shandong Provincial Natural Science Foundation, China (No. ZR2020ME184), National Key Research and Development Program of China (No. 2019YFD1100602), the National Natural Science Foundation of China (Nos. 51606113 and 51406108), and the SDUT \& Zhoucun City Integration Development Project (No. 2020ZCXCZH09).

\section{REFERENCES CITED}

Bender, T. A., Dabrowski, J. A., and Gagné Michel, R. M. (2018). "Homogeneous catalysis for the production of low-volume, high-value chemicals from biomass," Nature Reviews Chemistry 2, 35-46. DOI: 10.1038/s41570-018-0005-y

Bi, D. M., Li, B. Z., Liu, S. J., Yi, W. M., Jiang, M., and Lin, Z. D. (2019). "Influence of pyrolysis and torrefaction pretreatment temperature on the pyrolysis product distribution," BioResources 14(1), 1185-1197. DOI: 10.15376/biores.14.1.1185-1197

Cai, C. M., Zhang, T., Kumar, R., and Wyman, C. E. (2014). "Integrated furfural production as a renewable fuel and chemical platform from lignocellulosic biomass," Journal of Chemical Technology and Biotechnology 89, 2-10. DOI: $10.1002 /$ jctb.4168

Chagas, B. M. E., Dorado, C., Serapiglia, M. J., Mullen, C. A., Boateng, A. A., Melo, M. A. A., and Ataide, C. H. (2016). "Catalytic pyrolysis-GC/MS of spirulina: evaluation of a highly proteinaceous biomass source for production of fuels and chemicals," Fuel 179, 124-134. DOI: 10.1016/j.fuel.2016.03.076

Chen, D. Y., Zheng, Z. C., Fu, K. X., Zeng, Z., Wang, J. J., and Lu, M. T. (2015). "Torrefaction of biomass stalk and its effect on the yield and quality of pyrolysis products," Fuel 159, 27-32. DOI: 10.1016/j.fuel.2015.06.078

Chen, Y. H., Chang, C. C., Chang, C. Y., Yuan, M. H., Ji, D. R., Shie, J. L., Lee, C. H., Chen, Y. H., Chang, W. R., Yang, T. Y., Hsu, T. C., Huang, M., Wu, C. H., Lin, F. C., and Ko, C. H. (2017). "Production of a solid bio-fuel from waste bamboo chopsticks by torrefaction for cofiring with coal," Journal of Analytical and Applied Pyrolysis 126, 315-322. DOI: 10.1016/j.jaap.2017.05.015

Chen, W. H., Wang, C. W., Kumar, G., Rosset, P., and Hsieh, T. H. (2018). "Effect of torrefaction pretreatment on the pyrolysis of rubber wood sawdust analyzed by py- 
GC/MS," Bioresource Technology 259, 469-473. DOI:

10.1016/j.biortech.2018.03.033

Du, S. C., Gamliel, D. P., Valla, J. V., and Bollas, G. M. (2016). "The effect of ZSM-5 catalyst support in catalytic pyrolysis of biomass and compounds abundant in pyrolysis bio-oils," Journal of Analytical and Applied Pyrolysis 122, 7-12. DOI: 10.1016/j.jaap.2016.11.002

Hassan, H., Lim, J. K., and Hameed, B. H. (2016). "Recent progress on biomass copyrolysis conversion into high-quality bio-oil," Bioresource Technology 221, 645655. DOI: 10.1016/j.biortech.2016.09.026

Hilten, R. N., Speir, R. A., Kastner, J. R., and Mani, S. (2013). "Effect of torrefaction on bio-oil upgrading over HZSM-5. Part 2: byproduct formation and catalyst properties and function," Energy Fuels 27, 844-856. DOI: 10.1021/ef301695c

Kabir, G., and Hameed, B. H. (2017). "Recent progress on catalytic pyrolysis of lignocellulosic biomass to high-grade bio-oil and bio-chemicals," Renewable and Sustainable Energy Reviews 70, 945-967. DOI: 10.1016/j.rser.2016.12.001

Kan, T., Strezov, V., and Evans, T. J. (2016). "Lignocellulosic biomass pyrolysis: A review of product properties and effects of pyrolysis parameters," Renewable and Sustainable Energy Reviews 57, 1126-1140. DOI: 10.1016/j.rser.2015.12.185

Karagöz, S., Kawakami, T., Kako, A., and Iiguni, Y. (2016). "Single shot pyrolysis and on-line conversion of lignocellulosic biomass with HZSM-5 catalyst using tandem micro-reactor-GC-MS," RSC Advances 6, 46108-46115. DOI: 10.1039/c6ra04225b.

Masnadi, M. S., Habibi, R., Kopyscinski, J., Hill, J. M., Bi, X. T., Lim, C., Ellis, N., and Grace, R. (2014). "Fuel characterization and co-pyrolysis kinetics of biomass and fossil fuels," Fuel 117, 1204-1214. DOI: 10.1016/j.fuel.2013.02.006

Medic, D., Darr, M., Shah, A, Potter, B, and Zimmerman, J. (2012). "Effects of torrefaction process parameters on biomass feedstock upgrading," Fuel 91, 147-154. DOI: 10.1016/j.fuel.2011.07.019

Mullen, C. A., and Boateng, A. A. (2015). "Production of aromatic hydrocarbons via catalytic pyrolysis of biomass over Fe-modified HZSM-5 zeolites," ACS Sustainable Chemistry and Engineering 3(7), 1623-1631. DOI: 10.1021/acssuschemeng.5b00335

Navarro, R. M., Guil-Lopez, R., Fierro, J. L. G., Mota, N., Jiménez, S., Pizarro, P., Coronado, J. M., and Serrano, D. P. (2018). "Catalytic fast pyrolysis of biomass over $\mathrm{Mg}$-Al mixed oxides derived from hydrotalcite-like precursors: Influence of $\mathrm{Mg} / \mathrm{Al}$ ratio," Journal Analytical and Applied Pyrolysis 134, 362-370. DOI:

10.1016/j.jaap.2018.07.001

Prabu, S. S., Asokan, M. A., Roy, R., Francis, S., and Sreelekh, M. K. (2017). "Performance, combustion and emission characteristics of diesel engine fueled with waste cooking oil bio-diesel/diesel blends with additives," Energy 122, 638-648.

DOI: $10.1016 /$ j.energy.2017.01.119

Pütün, E. (2010). "Catalytic pyrolysis of biomass: Effects of pyrolysis temperature, sweeping gas flow rate and MgO catalyst," Energy 35, 2761-2766. DOI: 10.1016/j.energy.2010.02.024

Schultz, E. L., Mullen, C. A., and Boateng, A. A. (2017). “Aromatic hydrocarbon production from eucalyptus urophylla pyrolysis over several metal-modified ZSM-5 catalysts," Energy Technology 5, 196-204. DOI: 10.1002/ente.201600206

Sharma, A., Preek, V., and Zhang, D. (2015). "Biomass pyrolysis-A review of modelling, process parameters and catalytic studies," Renewable and Sustainable Energy Reviews 50, 1081-1096. DOI: 10.1002/chin.201609249

Sheldon, R. A. (2014). "Green and stainable manufacture of chemicals from biomass: 
state of the art," Green Chemistry 16, 950-963. DOI: 10.1039/c3gc41935e

Sommerhuber, P. F., Welling, J., and Krause, A. (2015). "Substitution potentials of recycled HDPE and wood particles from post-consumer packaging waste in woodplastic composites," Waste Management 46, 76-85. DOI:

10.1016/j.wasman.2015.09.011

Trubetskaya, A., Larsen, F. H., Shchukarev, A., Stahl, K., and Umeki, K. (2018). "Potassium and soot interaction in fast biomass pyrolysis at high temperatures," Fuel 225, 89-94. DOI: 10.1016/j.fuel.2018.03.140

Wang, X. H., Wu, J., Chen, Y. Q., Adisak, P., Yang, H. P., and Chen, H. P. (2018). "Comparative study of wet and dry torrefaction of corn stalk and the effect on biomass pyrolysis polygeneration," Bioresource Technology 258, 88-97. DOI: 10.1016/j.biortech.2018.02.114

Wang, X. X., Hu, X. Y., Song, C. S., and Lux, K. W. (2017). “Oligomerization of biomass-derived light olefins to liquid fuel: Effect of alkali treatment of HZSM-5 catalyst," Industrial \& Engineering Chemistry Research 56(42), 12046-12055. DOI: 10.1021/acs.iecr.7b02316

Xue, X. F., Pan, Z. Y., Zhang, C. S., Wang, D. T., Xie, Y. Y., and Zhang, R. Q. (2018). "Segmented catalytic co-pyrolysis of biomass and high-density polyethylene for aromatics production with $\mathrm{MgCl}_{2}$ and HZSM-5," Journal Analytical and Applied Pyrolysis 134, 209-217. DOI: 10.1016/j.jaap.2018.06.010

Yildiz, G., Ronsse, F., Duren, R. V., and Prins, W. (2016). "Challenges in the design and operation of processes for catalytic fast pyrolysis of woody biomass," Renewable and Sustainable Energy Reviews 57, 1596-1610. DOI: 10.1016/j.rser.2015.12.202

Yoo, H. S., and Choi, H. S. (2016). "A study on torrefaction characteristics of waste sawdust in an auger type pyrolyzer," Journal of Mater Cycles and Waste Management 18, 460-468. DOI: 10.1007/s10163-016-0482-3

Zeng, K., Yang, Q., Zhang, Y., Mei, Y. Y., Wang, X. H., Yang, H. P., Shao, J. G., Li, J. S., and Chen, H. P. (2018). "Influence of torrefaction with Mg-based additives on the pyrolysis of cotton stalk," Bioresource Technology 261, 62-69. DOI: 10.1016/j.biortech.2018.03.094

Zhang, H. Y., Zheng, J., Xiao, R., and Shen, D. K. (2013). "Co-catalytic pyrolysis of biomass and waste triglyceride seed oil in a novel fluidized bed reactor to produce olefins and aromatics integrated with self-heating and catalyst regeneration processes," RSC Advances 3, 5769-5774. DOI: 10.1039/c3ra40694f

Zhang, Z. B., Lu, Q., Ye, X. N., Li, W. T., Hu, B., and Dong, C. Q. (2015). "Production of phenolic-rich bio-oil from catalytic fast pyrolysis of biomass using magnetic solid base catalyst," Energy Conversion and Management 106, 1309-1317. DOI: 10.1016/j.enconman.2015.10.063

Zhang, Z. Z., Zhu, M. M., and Zhang, D. A. (2018). "A thermogravimetric study of the characteristics of pyrolysis of cellulose isolated from selected biomass," Applied Energy 220, 87-93. DOI: 10.1016/j.apenergy.2018.03.057

Zheng, Y. W., Yang, X. Q., Shen, H. J., Huang, Y. B., and Zheng, Z. F. (2018). "Preparation of modified hierarchical ZSM-5 catalyst and its application on pyrolysis of biomass to enhance aromatics products," Transactions of the Chinese Society of Agricultural Engineering 34, 240-250. DOI: 10.11975/j.issn.1002-6819.2018.20.031

Article submitted: Jan 27, 2021; Peer review completed: March 14, 2021; Revised version received and accepted: March 26, 2021; Published: April 2, 2021.

DOI: $10.15376 /$ biores.16.2.3706-3717 